\title{
An Experimental Investigation on Effect of Fly Ash on Egg Shell Concrete
}

\author{
G. Anisha \\ Department of Civil Engineering, \\ Chirala Engineering College, \\ Chirala, Andhra Pradesh, India
}

\author{
A. Pavani \\ Department of Civil Engineering, \\ Chirala Engineering College, \\ Chirala, Andhra Pradesh, India
}

\begin{abstract}
Egg shell which is made of calcium is thrown away as a waste. When the calcium carbonate is heated a binding material called Calcium Oxide (Lime) is obtained. As lime is the major compound of Portland cement, eggshell powder can be used as partial replacement of fine aggregate.
\end{abstract}

Fly Ash is one of the residues generated in the combustion of coal. Fly ash includes substantial amounts if Silicon dioxide $\left(\mathrm{SiO}_{2}\right)$ and Calcium Oxide $(\mathrm{CaO}) .75$ million tons of fly ash which are rich in Silica is disposed to landfill as a waste annually in India.

This project aims at examining the feasibility of eggshell powder as a partial replacement of fine aggregate and also to observe the affect of fly ash on the proposed concrete.

In the present study, concrete cubes of grade M30 and M40 were prepared in the laboratory by replacing the fine aggregate with fly ash and egg shell powder at combined proportions of $0 \%, 7 \%, 14 \%, 21 \%, 28 \%$, $35 \%$ \& $42 \%$ by weight. Tests are conducted at 7 days and 28 days on concrete cubes, cylinders and flexural beams to study compressive strength, split tensile strength and flexural strength/ finally the results are compared with the normal conventional concrete and the effect of fly ash on it is studied

KEYWORD: Concrete, Eggshell Powder, Fly Ash, Fine Aggregate, Compressive Strength, Split Tensile Strength and Flexural Strength

\section{Introduction}

Concrete is a mixture of cement, sand, coarse aggregate and water. Its success lies in its versatility as can be designed to withstand harshest environments while taking on the most inspirational forms. Engineers and scientists are further trying to increase its limits with the help of innovative chemical admixtures and various supplementary cementitious materials SCMs.

Early SCMs consisted of natural, readily available materials like volcanic ash or diatomaceous earth. The engineering marvels like Roman aqueducts, the Coliseum are examples of this technique used by Greeks and Romans. Nowadays, most concrete mixture contains SCMs which are mainly byproducts or waste materials from other industrial processes.

\section{MATERIALS}

\section{A. Cement:}

Cement is a material, generally in powder form, that can be made into a paste usually by the addition of water and, when molded or poured, will set into a solid mass. Numerous organic compounds used for adhering, or fastening materials, are called cements, but these are classified as adhesives, and the term cement alone means a construction material. The most widely used of the construction cements is Portland cement. It is a bluish-gray powder obtained by finely grinding the clinker made by strongly heating an intimate mixture of calcareous and argillaceous minerals. The chief raw material is a mixture of highcalcium limestone, known as cement rock, and clay or shale. Blast-furnace slag may also be used in some cements and the cement is called Portland slag cement (PSC). The color of the cement is due chiefly to iron oxide. In the absence of impurities, the color would be white, but neither the color nor the specific gravity is a test of quality. 
Table 1 Chemical Composition of Portland cement

\begin{tabular}{|c|c|c|}
\hline $\begin{array}{c}\text { Oxide } \\
\text { Composition }\end{array}$ & Abbreviation & $\begin{array}{c}\text { Percent } \\
\text { content }\end{array}$ \\
\hline Lime & $\mathrm{CaO}$ & $\mathbf{6 0 - 6 7}$ \\
\hline Silica & $\mathrm{SiO}_{2}$ & $\mathbf{1 7 - 2 5}$ \\
\hline Alumina & $\mathrm{Al}_{2} \mathrm{O}_{3}$ & $\mathbf{3 . 0 - 8 . 0}$ \\
\hline Iron Oxide & $\mathrm{Fe}_{2} \mathrm{O}_{3}$ & $\mathbf{0 . 5}-6.0$ \\
\hline Sulphate & $\mathrm{SO}_{3}$ & $\mathbf{1 . 3 - 3 . 0}$ \\
\hline Magnesia & $\mathrm{MgO}$ & $\mathbf{0 . 1 - 4 . 0}$ \\
\hline Alkalies & $\mathbf{K}_{\mathbf{2}} \mathbf{O}, \mathbf{N a}_{2} \mathbf{O}$ & $\mathbf{0 . 4 - 1 . 3}$ \\
\hline
\end{tabular}

\section{B. Fly Ash}

Class F fly ash obtained from thermal power plant at Vijayawada in Andhra Pradesh was used in this investigation. It was sieved through 90 micron sieve for the purpose of concreting samples. Specific Gravity of FA was 2.10. Fineness of FA was $310 \mathrm{~m} 3 / \mathrm{kg}$. Bulk Density of FA was $0.749 \mathrm{gm} / \mathrm{cm} 3$ conforming to IS: 3812-1981.

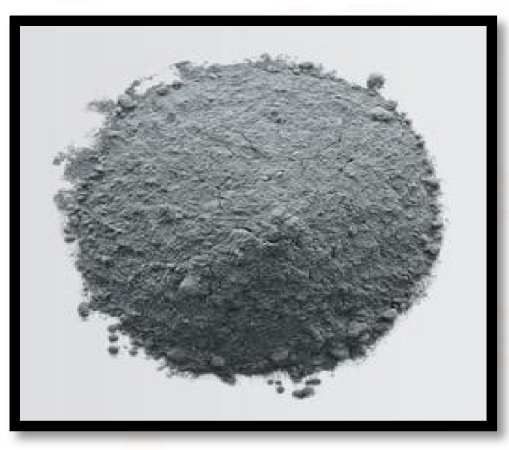

Figure 1 Fly Ash

Table 2 Chemical composition of fly ash

\begin{tabular}{|c|c|}
\hline Oxide Composition & Percent content \\
\hline Loss on ignition & 4.5 \\
\hline $\mathrm{SiO}_{2}$ & 56.65 \\
\hline $\mathrm{Al}_{2} \mathrm{O}_{3}$ & 27.35 \\
\hline $\mathrm{Fe}_{2} \mathrm{O}_{3}$ & 4.79 \\
\hline $\mathrm{CaO}$ & 2.19 \\
\hline $\mathrm{MgO}$ & 0.57 \\
\hline Soluble $\mathrm{SiO}_{2}$ & 3.95 \\
\hline
\end{tabular}

\section{Egg Shell Powder}

The eggshells (ES) were collected from domestic sources. The ES was washed manually and then left to dry at ambient conditions. In order to satisfy the physical requirement for fineness, ES was ground fine enough to pass through a $75 \mu \mathrm{m}$ sieve.

This is accomplished by crushing and grinding the eggshells manually and then sieving the ground ESP to the desired particle size.

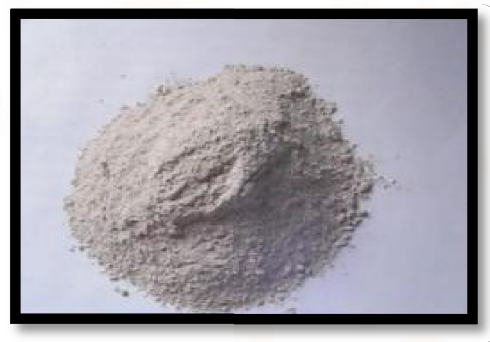

Figure 2 Egg shell powder

Table 3 Chemical composition of egg shell powder

\begin{tabular}{|c|c|}
\hline Oxide composititon & Percent content \\
\hline $\mathrm{CaO}$ & 50.7 \\
\hline $\mathrm{SiO}_{2}$ & 0.09 \\
\hline $\mathbf{A l}_{2} \mathbf{O}_{3}$ & 0.03 \\
\hline MgO & 0.01 \\
\hline $\mathrm{Fe}_{2} \mathrm{O}_{3}$ & 0.02 \\
\hline $\mathrm{Na}_{2} \mathrm{O}$ & 0.19 \\
\hline $\mathbf{P}_{2} \mathbf{O}_{5}$ & 0.24 \\
\hline SrO & 0.13 \\
\hline $\mathrm{NiO}$ & 0.0001 \\
\hline $\mathrm{SO}_{3}$ & $\mathbf{0 . 5 7}$ \\
\hline $\mathrm{Cl}$ & 0.219 \\
\hline
\end{tabular}

\section{Fine Aggregate}

Fine aggregate / sand is an accumulation of grains of mineral matter derived from the disintegration of rocks. It is distinguished from gravel only by the size of the grains or particles, but is distinct from clays which contain organic materials. Sands that have been sorted out and separated from the organic material by the action of currents of water or by winds across arid lands are generally quite uniform in size of grains. Usually commercial sand is obtained from river beds or from sand dunes originally formed by the action of winds. Much of the earth's surface is sandy, and these sands are usually quartz and other siliceous materials. 
The most useful commercially are silica sands, often above $98 \%$ pure. Beach sands usually have smooth, spherical to ovaloid particles from the abrasive action of waves and tides and are free of organic matter. The white beach sands are largely silica but may also be of zircon, monazite, garnet, and other minerals, and are used for extracting various elements.

Natural river sand confirming to Zone 2 grading as per IS: 383 - 1987 was used. The sand was thoroughly flushed with water to reduce the level of impurities and organic matter and later sun dried.

\section{Table 4 Physical properties of Fine aggregate}

\begin{tabular}{|c|l|c|}
\hline Sl.No & Parameters & Values \\
\hline $\mathbf{1 .}$ & $\begin{array}{l}\text { Specific } \\
\text { gravity }\end{array}$ & $\mathbf{2 . 9}$ \\
\hline $\mathbf{2 .}$ & $\begin{array}{l}\text { Fineness } \\
\text { modulus }\end{array}$ & $\mathbf{3 . 2}$ \\
\hline 3. & Bulk Density & $\mathbf{1 5 6 0 k g} / \mathbf{m}^{\mathbf{3}}$ \\
\hline 4. & $\begin{array}{l}\text { Moisture } \\
\text { Content }\end{array}$ & $\mathbf{1 . 5 0 \%}$ \\
\hline
\end{tabular}

\section{E. Coarse Aggregate}

Coarse aggregate are the crushed stone is used for making concrete. The commercial stone is quarried, crushed, and graded. Much of the crushed stone used is granite, limestone, and trap rock. The last is a term used to designate basalt, gabbro, diorite, and other dark-colored, fine-grained igneous rocks. Graded crushed stone usually consists of only one kind of rock and is broken with sharp edges. The sizes are from 0.25 to 2.5 in $(0.64$ to $6.35 \mathrm{~cm})$, although larger sizes may be used for massive concrete aggregate. Machine crushed granite broken stone angular in shape was used as coarse aggregate. The maximum size of coarse aggregate was $20 \mathrm{~mm}$ and specific gravity of 2.78 . Granite is a coarse-grained, igneous rock having an even texture and consisting largely of quartz and feldspar with often small amounts of mica and other minerals. There are many varieties. Granite is very hard and compact, and it takes a fine polish, showing the beauty of the crystals. Granite is the most important building stone. Granite is extremely durable, and since it does not absorb moisture, as limestone and sandstone do, it does not weather or crack as these stones do. The colors are usually reddish, greenish, or gray. Rainbow granite may have a black or dark-Green background with pink, yellowish, and reddish mottling; or it may have a pink or lavender background with dark mottling.

The natural broken stone (coarse aggregate) used for the study was of $20 \mathrm{~mm}$ size maximum.

\section{F. Water}

Water fit for drinking is generally considered fit for making concrete. Water should be free from acids, oils, alkalies, vegetables or other organic Impurities. Soft waters also produce weaker concrete. Water has two functions in a concrete mix. Firstly, it reacts chemically with the cement to form a cement paste in which the inert aggregates are held in suspension until the cement paste has hardened. Secondly, it serves as a vehicle or lubricant in the mixture of fine aggregates and cement.

\section{METHODOLOGY}

In order to study the mechanical properties of fly ash and egg shell powder concrete. Six mix proportions were made. The percentage replacements of aggregates by fly ash and egg shell powder were $0 \%, 7 \%, 14 \%$, $21 \%, 28 \% 35 \%$ and $42 \%$. This was done to determine the proportion that would give the most favorable result. The $0 \%$ replacement was to serve as control for other sample which is finally used for the comparison. The mix proportions studied for the fly ash and egg shell powder concrete are totally 5 proportions. The mix proportion was done as per the IS: 10262-1982. The target mean strength was 39.9 and $50.89 \mathrm{~N} / \mathrm{mm}^{2}$ for M30 and M40. The final mix that is used $1: 1.13: 2.36$ and $1: 1.07: 2.20$ is obtained for water cement ratio is 0.38 and 0.31 .

\section{TEST PROGRAM}

The cubes of $150 \times 150 \times 150 \mathrm{~mm}$ size and cylinders of $150 \mathrm{~mm}$ diaX $300 \mathrm{~mm}$ and beams of 100X100X500mm, were tested for Compression, Split Tensile and Flexural Strength. Tests were done as per following codes of Bureau of Indian Standards. The test for Compressive Strength on cubes were measured at 7 and 28 days of curing as per IS:5161959, test for Flexural Strength on beam was measured at 7 and 28 days of curing as per IS:5161959 and test for Split Tensile Strength on cylinder was measured at 7 and 28 days of curing as per IS:5816-1999. 


\section{PROPORTIONS OF TEST SPECIMENS}

The present experimental programme includes casting and testing of specimens for compressive strength. Specimens are prepared for M30 \& M40 grades of concrete with different percentages of FLY ASH and EGG SHELL POWDER. The cube specimens are cast. The details of casting and testing of specimens are described below

Table 5 Mix Proportions

\begin{tabular}{|c|c|c|c|c|}
\hline S.No & Mix & Flyash \% & $\begin{array}{c}\text { Eggshell } \\
\text { Powder } \%\end{array}$ & Combined \\
\hline $\mathbf{1}$ & M1 & 0 & 0 & $\mathbf{0}$ \\
\hline $\mathbf{2}$ & M2 & 3.5 & 3.5 & $\mathbf{7}$ \\
\hline $\mathbf{3}$ & M3 & 7 & 7 & $\mathbf{1 4}$ \\
\hline $\mathbf{4}$ & M4 & 10.5 & 10.5 & $\mathbf{2 1}$ \\
\hline $\mathbf{5}$ & M5 & 14 & 14 & $\mathbf{2 8}$ \\
\hline $\mathbf{6}$ & M6 & 17.5 & 17.5 & $\mathbf{3 5}$ \\
\hline $\mathbf{7}$ & M7 & $\mathbf{2 1}$ & $\mathbf{2 1}$ & $\mathbf{4 2}$ \\
\hline
\end{tabular}

\section{MIXING}

For each mix, the required quantities of the constituents were batched by weight. The mix design is produced for maximum size of the aggregate is $20 \mathrm{~mm}$ conventional aggregate FA and ESP with replacement of FA and ESP respectively and combinely with fine aggregate by $7 \%, 14 \%, 21 \%$, $28 \%, 35 \%, 42 \%$, is studied by casting cubes, cylinders and beams.

Water is weighed exactly and added to the dry mix and entire mix is thoroughly mixed till uniformity is arrived at. The fresh concrete is tested using compaction factor apparatus for workability immediately after thoroughly mixing.

\section{WORKABILITY:}

In an indirect by determining the degree of compaction achieved by a standard amount of work done compaction factor measures the workability by allowing the concrete to fall through a standard height. In the upper hopper up to the brim the sample of concrete to be tested is placed. So that the concrete falls in the lower hopper the trap door is opened. Concrete is allowed to fall into the cylinder the trap door of the lower hopper is opened and. It is likely that the concrete may not fall on opening trap door in the case of a dry mix. In such case a slight pocking by the rod may be required to set the concrete in motion. The excess concrete remaining top level of cylinder is then cut off with the help of plain blades supplied with apparatus. The surface of cylinder is wiped clean and weighed to the nearest $10 \mathrm{gms}$. This weight is known as "weight of partially compacted concrete". The cylinder is emptied and then refilled with the concrete from the sample in layers of each about $5 \mathrm{~cm}$ depth. The layers are heavily rammed or preferably vibrated so as to obtain full compaction. The top surface of fully compacted concrete is then carefully struck off and the cylinder is weighed to the nearest $10 \mathrm{gms}$. The weight is known of fully compacted concrete.

Compaction Factor $=$ Weight of partially compacted concrete/weight of fully compacted concrete. The compaction factor is calculated for various percentages of silica fume concretes and various ordinary concretes keeping the water -cement ratio constant. A compaction factor value of $0.82-0.9$ has been maintained throughout the experimentation.

\section{CASTING OF SPECIMENS}

For casting the cubes, standard C.I Metal cubes of size $150 \mathrm{~mm} \times 150 \mathrm{~mm}$ have been used. The moulds have been cleaned of dust particles and applied with mineral oil on all sides, before concrete is poured into the mould. Thoroughly mixed concrete is filled into the mould.

\section{CURING OF SPECIMENS}

After casting the molded specimens are stored in the laboratory free from vibrations, in moist air and at room temperature for $24 \mathrm{hrs}$. After this period, the specimen are removed from the moulds and immediately submerged in the clean fresh water of curing tank. The curing water is renewed after every 5 days. The specimens are cured for 7 and 28 days in the present work.

\section{TESTING OF CUBE SPECIMENS}

After 7 days \& 28 days the specimens are removed and the following tests were tested and the results compared with conventional concrete. 
$>$ Compressive strength test

$>$ Flexural strength test

$>$ Split tensile strength test

\section{RESULTS}

The cubes of $150 \times 150 \times 150 \mathrm{~mm}$ size and cylinders of $150 \mathrm{~mm}$ diaX $300 \mathrm{~mm}$ and beams of 100X100X500mm, were tested for Compression, Split Tensile and Flexural Strength. Tests were done as per following codes of Bureau of Indian Standards. The test for Compressive Strength on cubes were measured at 7 and 28 days of curing as per IS:516-1959, test for Flexural Strength on beam was measured at 7 and 28 days of curing as per IS:516-1959 and test for Split Tensile Strength on cylinder was measured at 7 and 28 days of curing as per IS:5816-1999.

\section{COMPRESSIVE STRENGTH OF CONCRETE}

The cubes are tested for compressive strength for 7 days and 28 days with the maximum nominal size of the aggregate as $20 \mathrm{~mm}$ and the average test results are noted.

\section{FLEXURAL STRENGTH OF CONCRETE}

The ability of a beam or slab to resist failure in bending is flexural strength. The flexural strength of concrete is 12 to 20 percent of compressive strength. The concrete prisms are tested for flexural strength for 7 days and 28 days.

\section{SPLIT TENSILE STRENGTH}

The concrete cylinders are tested for split tensile strength for 7 days and 28 days. The split tensile strength is determined by dividing the maximum applied load by appropriate geometrical factors.

\section{RESULTS FOR M30 GRADE CONCRETE}

Table 6 Average Compressive strength values for M30

\begin{tabular}{|c|c|c|c|c|c|c|}
\hline $\begin{array}{c}\text { S. } \\
\text { N }\end{array}$ & MI & $\begin{array}{c}\text { FL } \\
\text { YA } \\
\text { SH }\end{array}$ & $\begin{array}{c}\text { EGGS } \\
\text { HELL } \\
\text { POW } \\
\text { DER }\end{array}$ & $\begin{array}{c}\text { COMB } \\
\text { INED } \\
\text { REPL } \\
\text { ACEM } \\
\text { ENT }\end{array}$ & \multicolumn{2}{|c|}{$\begin{array}{c}\text { COMPRESSI } \\
\text { VTENGTH } \\
\text { N/mm2 }\end{array}$} \\
\hline & & $\%$ & $\%$ & $\%$ & 7 days & $\begin{array}{c}28 \\
\text { days }\end{array}$ \\
\hline 1 & M1 & 0 & 0 & 0 & 25.75 & 37.59 \\
\hline 2 & M2 & 3.5 & 3.5 & 7 & 30.94 & 44.25 \\
\hline 3 & M3 & 7 & 7 & 14 & 28.56 & 41.22 \\
\hline 4 & M4 & 10.5 & 10.5 & 21 & 27.12 & 40.23 \\
\hline 5 & M5 & 14 & 14 & 28 & 25.43 & 39.51 \\
\hline 6 & M6 & 17.5 & 17.5 & 35 & 20.25 & 30.15 \\
\hline 7 & M7 & 21 & 21 & 42 & 15.36 & 21.06 \\
\hline
\end{tabular}

Table 7 Average Flexural strength values for M30 grade

\begin{tabular}{|c|c|c|c|c|c|c|}
\hline $\begin{array}{c}\text { S. } \\
\text { N }\end{array}$ & MIX & $\begin{array}{c}\text { FLY } \\
\text { AS } \\
\text { H }\end{array}$ & $\begin{array}{c}\text { EGGS } \\
\text { HIEL } \\
\text { POWD } \\
\text { ER }\end{array}$ & $\begin{array}{c}\text { COMB } \\
\text { INED } \\
\text { REPL } \\
\text { ACEM } \\
\text { ENT }\end{array}$ & \multicolumn{2}{|c|}{$\begin{array}{c}\text { FLEXURAL } \\
\text { STRENGTH } \\
\text { N/mm2 }\end{array}$} \\
\hline & & $\%$ & $\%$ & $\%$ & 7 days & $\begin{array}{c}28 \\
\text { days }\end{array}$ \\
\hline 1 & M1 & 0 & 0 & 0 & 3.19 & 4.33 \\
\hline 2 & M2 & 3.5 & 3.5 & 7 & 3.55 & 4.56 \\
\hline 3 & M3 & 7 & 7 & 14 & 3.26 & 4.26 \\
\hline 4 & M4 & 10.5 & 10.5 & 21 & 2.46 & 3.75 \\
\hline 5 & M5 & 14 & 14 & 28 & 2.21 & 3.42 \\
\hline 6 & M6 & 17.5 & 17.5 & 35 & 1.76 & 2.99 \\
\hline 7 & M7 & 21 & 21 & 42 & 1.12 & 2.48 \\
\hline
\end{tabular}




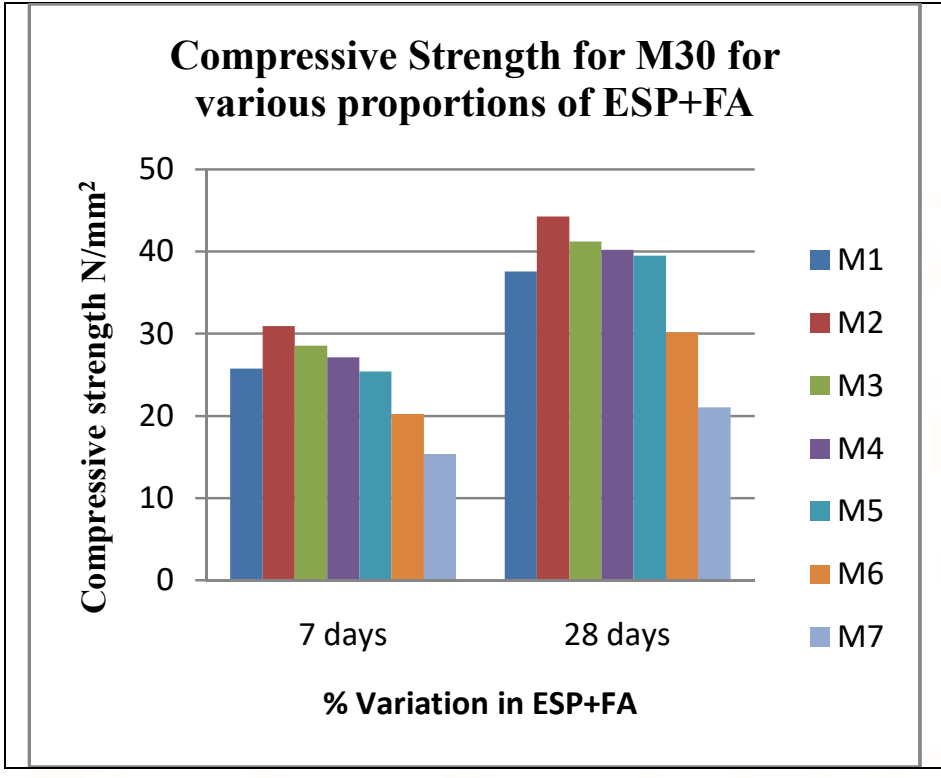

Fig 3 Compressive strength for 7 days and 28 days (M30)

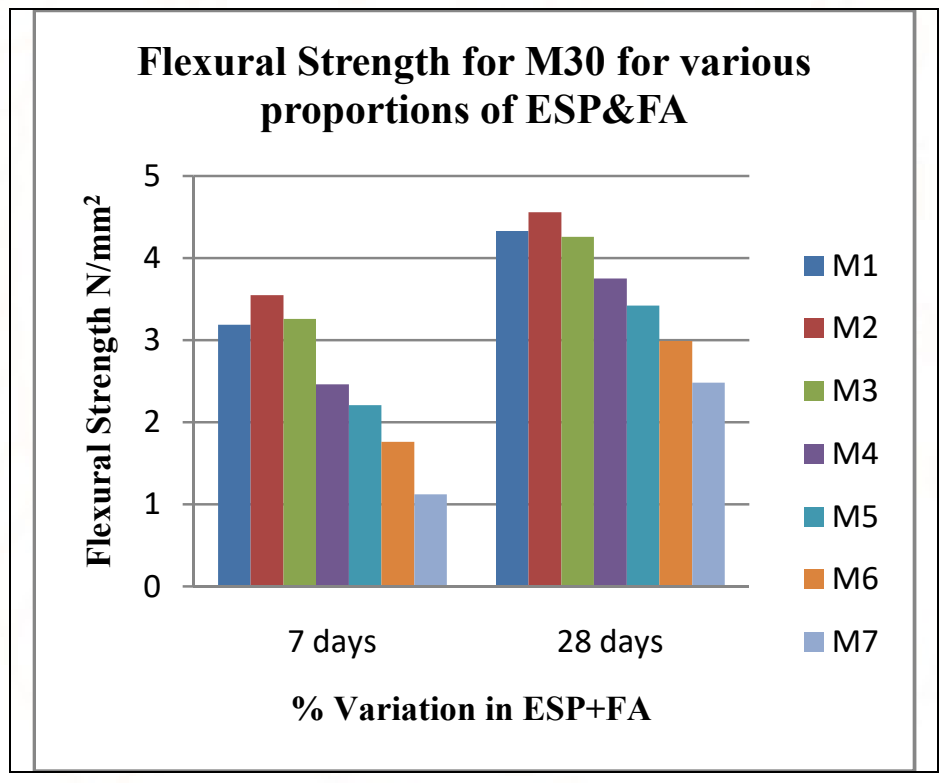

Fig 4 Flexural strength for 7 days and 28 days (M30)

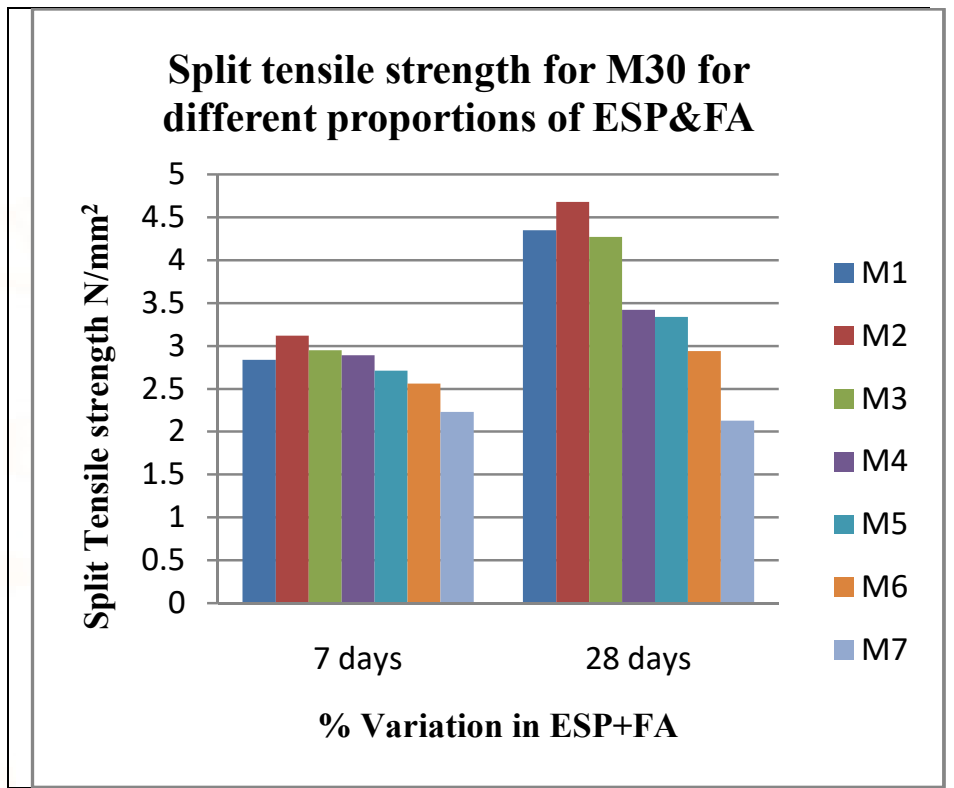

Fig 5 Split Tensile strength for 7 days and 28 days (M30)

Table 8 Average Split tensile strength values for M30

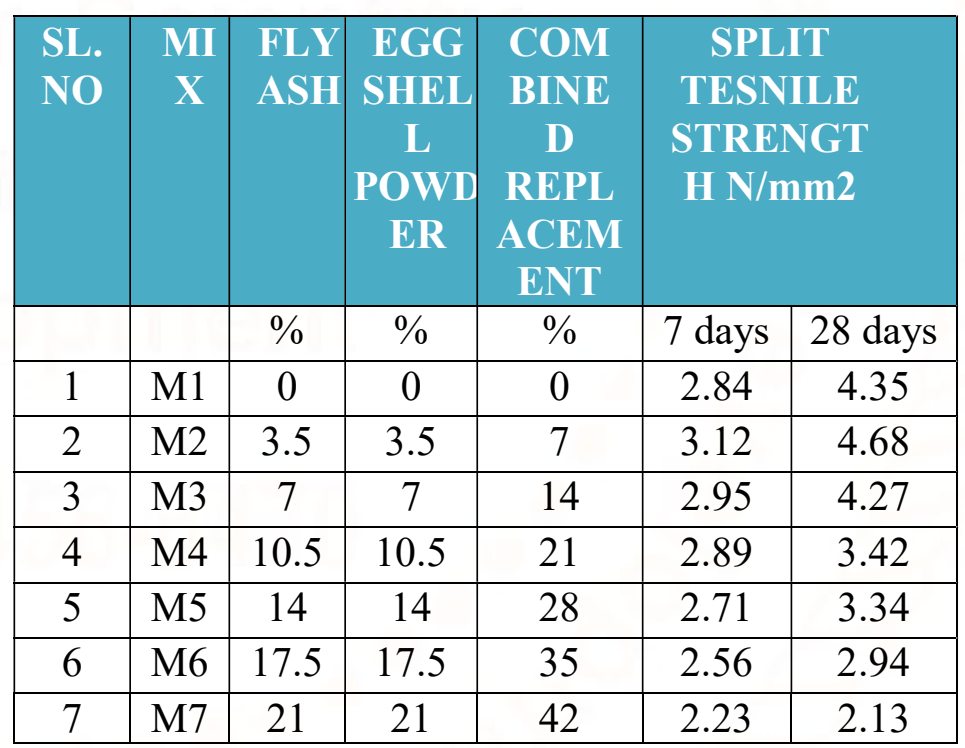


International Journal of Trend in Scientific Research and Development, Volume 1(4), ISSN: 2456-6470 www.ijtsrd.com

RESULTS FOR M40 GRADE CONCRETE

Table 9 Average Compressive strength values for M40

\begin{tabular}{|c|c|c|c|c|c|c|}
\hline S. & MIX & FL & EGGS & COM & \multicolumn{2}{|c|}{ COMPRESSI } \\
O & & $\begin{array}{c}\text { Y } \\
\text { AS } \\
\text { H }\end{array}$ & $\begin{array}{c}\text { HELL } \\
\text { POW } \\
\text { DIR }\end{array}$ & $\begin{array}{c}\text { DINE } \\
\text { REPL } \\
\text { ACE } \\
\text { MIEN } \\
\text { T }\end{array}$ & \multicolumn{2}{|c|}{$\begin{array}{c}\text { VTRENGTH } \\
\text { N/mm2 }\end{array}$} \\
\hline & & $\%$ & $\%$ & $\%$ & $\begin{array}{c}7 \\
\text { days }\end{array}$ & $\begin{array}{c}28 \\
\text { days }\end{array}$ \\
\hline 1 & M1 & 0 & 0 & 0 & 31.62 & 46.22 \\
\hline 2 & M2 & 3.5 & 3.5 & 7 & 32.04 & 46.88 \\
\hline 3 & M3 & 7 & 7 & 14 & 31.54 & 46.45 \\
\hline 4 & M4 & 10. & 10.5 & 21 & 29.74 & 45.86 \\
\hline 5 & M5 & 14 & 14 & 28 & 26.63 & 40.96 \\
\hline 6 & M6 & 17. & 17.5 & 35 & 23.37 & 37.33 \\
\hline 7 & M7 & 21 & 21 & 42 & 20.25 & 32.76 \\
\hline
\end{tabular}

Table 10 Average Flexural strength values for M40 grade

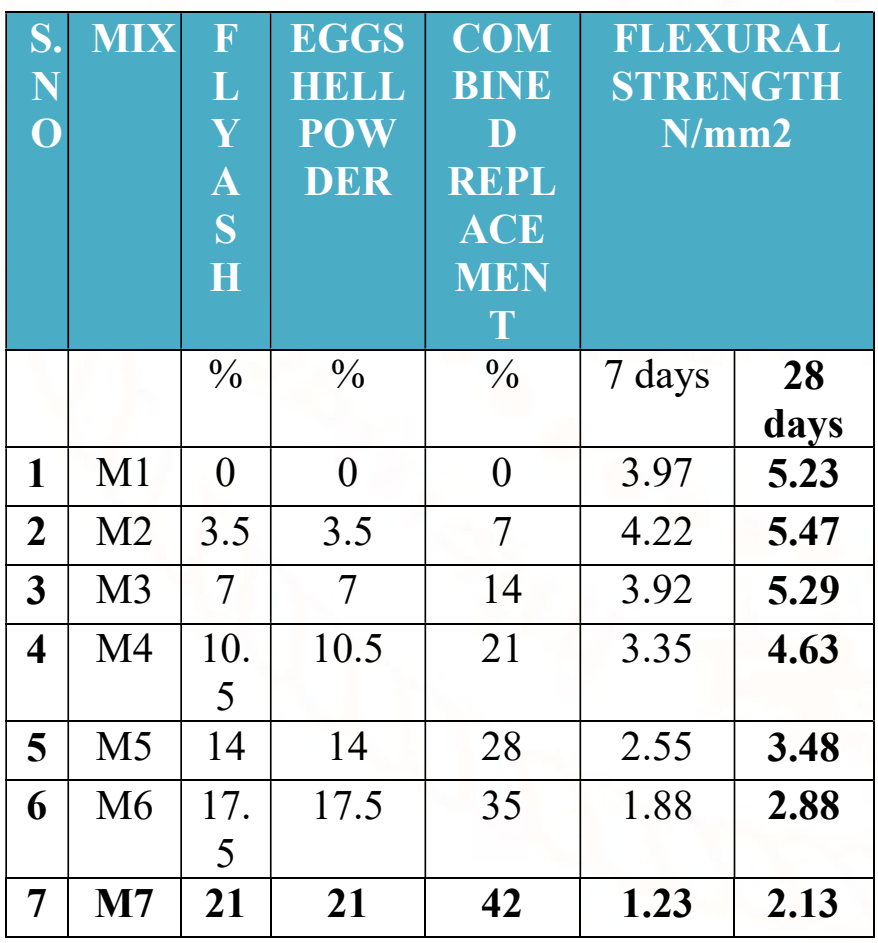

Table 11 Average Split tensile strength values for M40

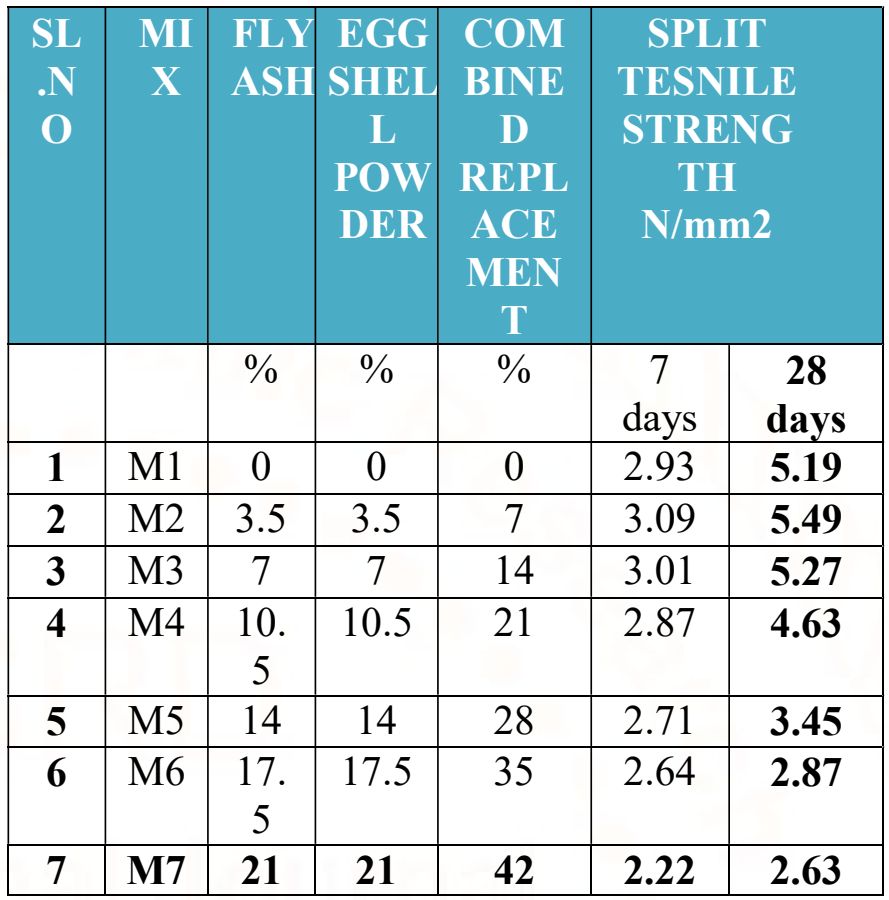

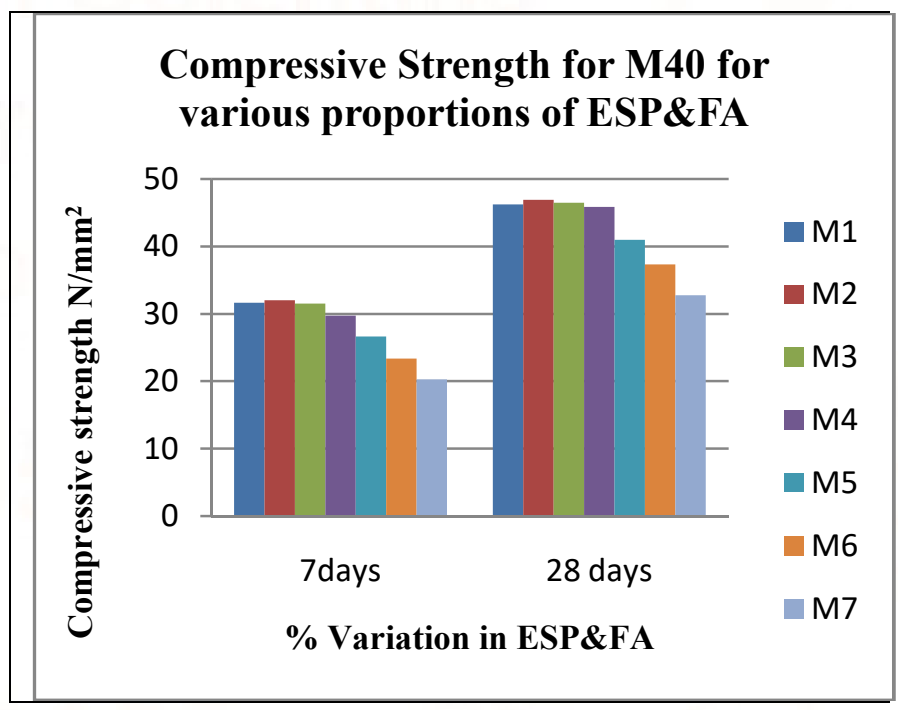

Fig 6 Compressive strength for 7 days and 28 days (M40) 


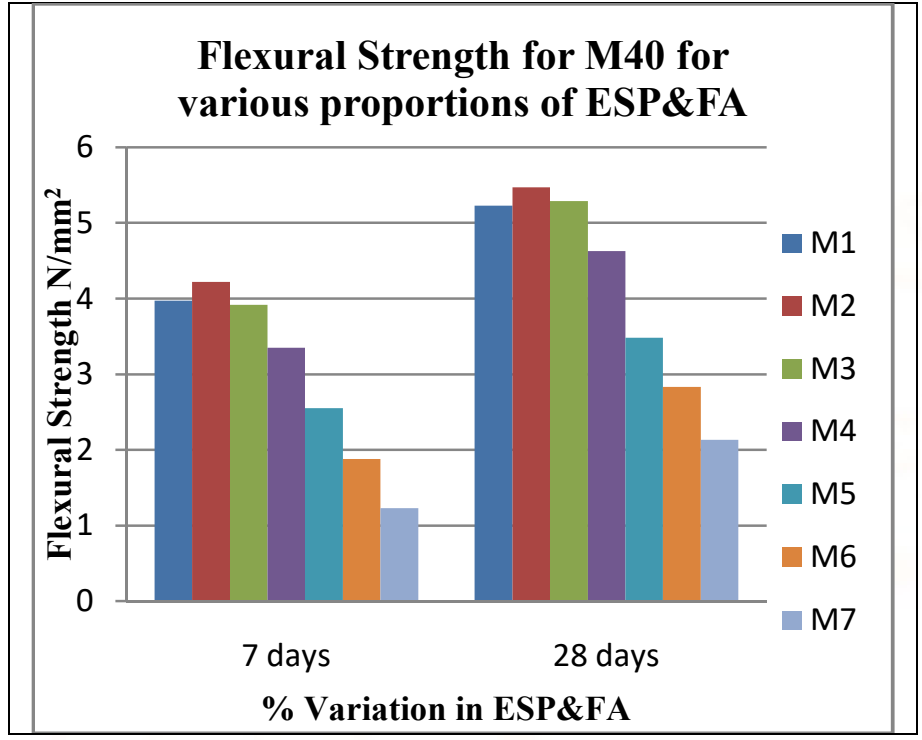

Fig 7 Flexural strength for 7 days and 28 days

(M40)

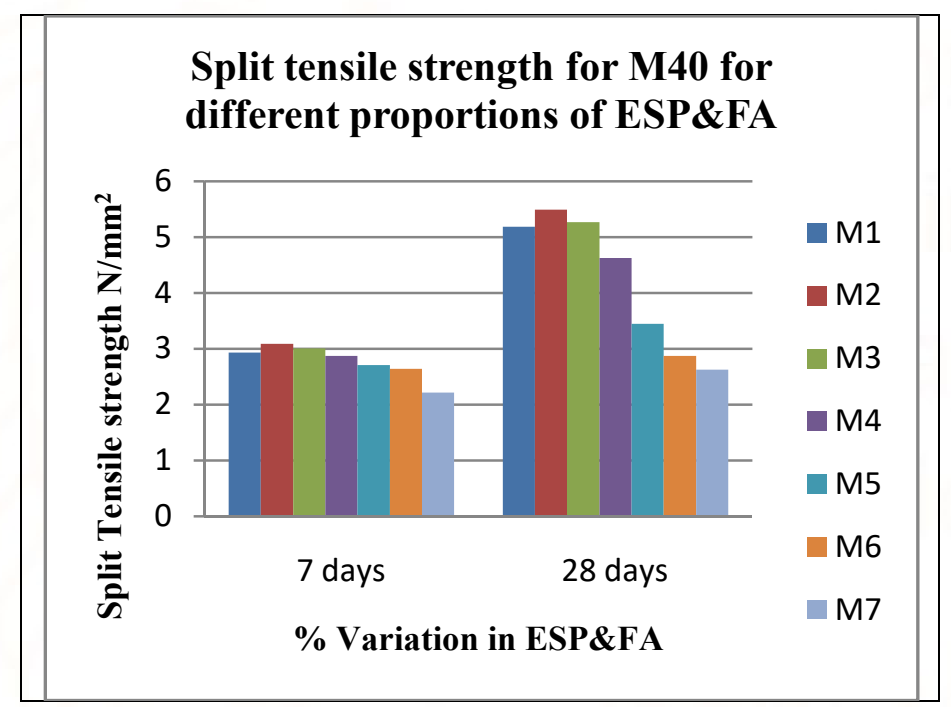

Fig 8 Split Tensile strength for 7 days and 28 days (M40)

\section{CONCLUSION}

Based on the experimental investigation conducted in the present project, the following Conclusions are drawn.

1. Inclusion of Fly Ash improves the strength of different types of egg shell concrete mix by making them more denser

2. Compressive strength, splitting tensile strength and flexural strength of fine aggregate partially replaced with FA and ESP concrete specimens were higher than the normal concrete specimens at
7 and 28 days. The strength differential between the FA and ESP concrete specimens and normal concrete specimens became more distinct after 28 days.

3. Compressive strength, splitting tensile strength and flexural strength of fine aggregate partially replaced with FA and ESP concrete continued to increase at certain level at 7 and 28 days.

4. Compressive strength was higher than normal concrete for $21 \%$ FA and ESP replacement at 7 and 28 days of curing ages. FA and ESP replacements greater than 28\% (M30) and 21\% (M40) had lower strength than nor-mal concrete at the same time weight of the cubes are reduced up to $7 \%$ per cube.

5. Split tensile strength of FA and ESP concrete were comparable with normal concrete up to $35 \%$ FA and ESP replacement. However, concrete with 14\% FA and ESP had lower split tensile strength than normal concrete at both the mixes.

6. Flexural strength of ESP and FP concrete were comparable with normal concrete up to $35 \%$ replacement. However, concrete with 14\% FA and ESP had lower flexural strength than normal concrete at both the mixes

7. Results of this investigation suggest that fly ash and egg shell could be very conveniently used in structural concrete

\section{REFERENCES}

1. Rafat Siddique, "Effect of fine aggregate replacement with class $F$ fly ash on the mechanical properties of concrete", cement and concrete research, 33 (2003) 539-547.

2. Amarnath Yerramala, "Properties of concrete with egg shell powder as cement replacement", The Indian concrete journal, October 2014.

3. Jayasankar.R, Mahindran.N, Hangovan.R, "Studies on concrete using fly ash, rice husk ash and egg shell powder", International journal of civil and structural engineering, Volume 1, No.3, 2010.

4. Mohammed Razzaq, Ahmed Namah Hadi, "Effect of egg shells powder on some mechanical and physical properties of natural rubber (NR)", The iraqi journal for mechanical and material engineering, Volume 22, No.3, 2012.

5. Okonkwo,U.N, Odiong,I.C. and Akpabio,E.E, "The effects of egg shell ash on strength 
properties of cement-stabilized lateritic", International journal of sustainable construction engineering \& technology, Volume 3,Issue 1, 2012.

6. Sathanantham.T, "Partially repalcement of fine aggregate by rice husk \& egg shell in concrete",Interna-tional journal of innovative research \& studies, ISSN 2319-9725, Volume 3, Issue 1, January 2014.

7. K.Uma shankar J \& H.V.Balaji, "Experimental analysis on effective utilization of industrial waste materials of egg shell, GGBS and saw dust ash", International journal of management, information technology \& engi-neering, Volume 2, Issue 1,Jan 2014.

8. Anu Paul, Anumol V S, Fathima Moideen, Jiksymol K Jose, Alka Abraham, "Studies on Improvement of Clayey Soil Using Egg Shell Powder and Quarry Dust" Journal of Engineering Research and Applications ISSN : 2248-9622, Vol. 4, Issue 4( Version 4), April 2014.

9. Khusbu Rajhans, Proff. C. R. Sharma, Studies on con-crete characteristic strength using fly ash and rice husk ash, International Journal of Engineering Research and Applications, ISSN: 2248-9622, Volume 4, Issue 2, February 2014.

10. M.S. SHETTY (1982) Concrete Technology, Sultan Chand Publication, 2nd edition.

11. ACI Committee 211.1-91 (1991), Standard Practice for Selecting Proportions for Normal, Heavyweight and Mass Concrete. Detroit, American Concrete Institute.

12. Concrete technology by A.M.NEVILLE.

13. Concrete technology by M.L.GAMBHIR.

14. Indian Standard Recommended Guidelines for Concrete Mix Design IS: 10262 - 1982.

15. Indian Standard Recommended Guidelines for Cement IS: $456-1978$.

16. IS 383:1970 - Specification for coarse and fine aggregates from natural sources for concrete.

17. IS 4031(Part 6):1988 Methods of physical tests for hydraulic cement: Part 6 Determination of compressive strength of hydraulic cement.

18. IS 10086:1982 Specification for moulds for use in tests of cement and concrete.
19. IS 10262:2009 Guidelines for concrete mix proportioning.

20. Nevill, A.M (2012). "Properties of Concrete", $5^{\text {th }}$ edition, Prentice Hall.

21. Jamal Khatib. (2009). "Sustainability of Construction Materials", Woodhead Publishing Series in Civil and Structural Engineering, p124.

22. Gowsika D., Sarankokila S. and K.Sargunan. (2014). "Experimental Investigation of Egg Shell Powder as Partial Replacement with Cement in Concrete", International Journal of Engineering Trends and Technology (IJETT), Vol. 14, No. 2, pp.65-68.

23. The Effect of Aggregate Properties on Concrete. Engr.psu.edu. Retrieved on 201302-19.

24. History of Concrete. Ce.memphis.edu. Retrieved on 2013-02-19.

25. Cement hydration". Understanding Cement. Retrieved 1 October 2012. 